\title{
The relationship between religion and psychological resilience against COVID-19
}

\begin{tabular}{|c|c|}
\hline $\begin{array}{l}\text { Authors: } \\
\text { Lubov K. Ilyas! } \\
\text { Tatyana N. Iva } \\
\text { Leisan N. Khas }\end{array}$ & $\begin{array}{l}\text { ienko }{ }^{1} \text { (D) } \\
\text { nova }^{2} \text { (D) } \\
\text { imova }^{3,4} \text { (D) }\end{array}$ \\
\hline \multicolumn{2}{|c|}{$\begin{array}{l}\text { Affiliations: } \\
{ }^{1} \text { Faculty of Social Sciences } \\
\text { and Humanities, Industrial } \\
\text { University of Tyumen, Surgut, } \\
\text { Russian Federation }\end{array}$} \\
\hline \multicolumn{2}{|c|}{$\begin{array}{l}{ }^{2} \text { Sociology Department, } \\
\text { Togliatti State University, } \\
\text { Togliatti, Russian Federation }\end{array}$} \\
\hline \multicolumn{2}{|c|}{$\begin{array}{l}{ }^{3} \text { Legal Department, Kazan } \\
\text { Federal University, Kazan, } \\
\text { Russian Federation }\end{array}$} \\
\hline \multicolumn{2}{|c|}{$\begin{array}{l}{ }^{4} \text { Dean's Office, Faculty of } \\
\text { Theology and Religion, } \\
\text { University of Pretoria, } \\
\text { Pretoria, South Africa }\end{array}$} \\
\hline \multicolumn{2}{|c|}{$\begin{array}{l}\text { Corresponding author: } \\
\text { Lubov Ilyashenko, } \\
\text { k_lu.90@yahoo.com }\end{array}$} \\
\hline \multicolumn{2}{|c|}{$\begin{array}{l}\text { Received: } 19 \text { Jan. } 2021 \\
\text { Accepted: } 19 \text { Apr. } 2021 \\
\text { Published: } 27 \text { Oct. } 2021\end{array}$} \\
\hline \multicolumn{2}{|c|}{$\begin{array}{l}\text { How to cite this article: } \\
\text { Ilyashenko, L.K., Ivanova, T } \\
\text { \& Khasimova, L.N., 2021, } \\
\text { 'The relationship between } \\
\text { religion and psychological } \\
\text { resilience against COVID-1 } \\
\text { HTS Teologiese Studies/ } \\
\text { Theological Studies 77(1), } \\
\text { a6486. https://doi.org/ } \\
\text { 10.4102/hts.v77i1.6486 }\end{array}$} \\
\hline \multicolumn{2}{|c|}{$\begin{array}{l}\text { Copyright: } \\
\text { (C) 2021. The Authors } \\
\text { Licensee: AOSIS. This } \\
\text { is licensed under the } \\
\text { Creative Commons } \\
\text { Attribution License. }\end{array}$} \\
\hline \multicolumn{2}{|l|}{ Read online: } \\
\hline 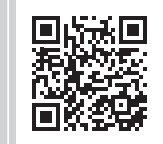 & $\begin{array}{l}\text { Scan this QR } \\
\text { code with your } \\
\text { smart phone or } \\
\text { mobile device } \\
\text { to read online. }\end{array}$ \\
\hline
\end{tabular}

The coronavirus disease 2019 (COVID-19) not only will have negative impacts on religious beliefs, but will also deepen them. Attention to Islamic teachings is significantly important in dealing with the COVID-19 pandemic. Nevertheless, the increased outbreak of COVID-19 in the world shows the need for humanity to pay more attention to religion and theology. Islam prevents diseases and motivates people to adhere to hygiene principles, and Islamic teachings bring about purity and health to people. However, paying attention to God, chanting prayers and focusing on spirituality are key principles in the prevention and treatment of diseases as this material cause is the divine will. Everyone is under the power of the Almighty, and everything is in his hands. Nevertheless, human beings may pass away because of COVID-19 even after passing all these stages. This is, however, related to divine destiny and is beyond the aim of this research study. One of the issues that relate religion to COVID-19 is psychological resilience, which is the topic of this study. This research study aimed at evaluating the role of religion and religiosity in the psychological resilience of 550 Muslim citizens from three cities of Aceh, Semarang and Jakarta, who had recovered from COVID-19. We applied the convenience sampling method to determine the sample size. After the distribution of questionnaires, 536 tools were considered suitable, and data analysis was performed using mean and correlation tests. According to the results, religiosity affected psychological resilience by $p=0.784$.

Contribution: The results of this study revealed that with increasing attention of people to religious teachings, the psychological resilience to the COVID-19 also increases.

Keywords: religion; religiosity; religious beliefs; Islam; psychological resilience; Indonesia; COVID-19.

\section{Introduction}

Resilience in a system refers to the ability to perform one's functions despite environmental fluctuations (Eskandari et al. 2016; Redadi, Najafi Farashah \& Azarfar 2016). This means that resilience can be defined for man, organisations, firms, nations, countries and social movements, and their resilience can be measured. The concept of resilience has been widely used in various fields of studies in the last four decades. More than 40 years ago, the term resilience was introduced in the psychological literature with an emphasis on individual resilience for the first time. Resilience is defined as the capacity of tolerating shocks and returning to the base state or at least having sufficient power to prevent systems from failure or collapse (Eskandari et al. 2016). Therefore, resilience is undoubtedly a public good. At the national level, resilience is interpreted as the process of adapting to adversities or changes caused by environmental threats (Molavi et al. 2019). In addition to psychology, the term 'resilience' has been used in other fields of studies, including political science, business management, sociology, history, crisis management and planning, urban planning and international development. However, this shared use does not mean that the concept has the same theoretical support in these areas. Various uses have different methodologies. There has been an increase in the use of the term 'resilience' in economics, especially since the financial crisis of 2008 .

In this regard, the World Economic Forum has published a special report relating to the 2013 Global Risk Report entitled 'Creating National Resilience against Global Risks' (Redadi et al. 2016). A social system is resilient when it is able to absorb temporary or permanent shocks and adapt to the changing situation rapidly without losing its stability. Social resilience is not just strengthening factors before an incident. In fact, social resilience relies on people's ability, who can creatively

Note: Special Collection: Faith Seeking Understanding, sub-edited by Seyed Mehdi Mousavi (Payame Noor University, Tehran, Iran) and the Dean's Office of the Faculty of Theology and Religion of the University of Pretoria. 
imagine a new future and then take the necessary steps towards a favourable future (Keshtkar \& Dehghan 2018). In other words, national resilience is like entering a boxing match, tolerating each strike and returning to one's initial state. The concept of national resilience shows the sustainability and strength of society in various fields. In other words, resilience is defined as the ability of countries, societies and families to manage a change whilst maintaining their living standards against stress or shocks (e.g. earthquakes, drought, diseases or violent conflicts) without compromising the long-term vision (Weichselgartner \& Kelman 2015).

Most of the countries struggling with the coronavirus disease 2019 (COVID-19) have imposed huge economic, cultural, political, social and psychological burdens on various communities (Nishiura et al. 2020). From a psychological perspective, a country, including its government and people, which deals with COVID-19, is supported when a type of social recognition shapes in it, and the beliefs and attitudes of the people collectively are projected towards resilience against the problem. In addition, they will be propelled towards commitment and control over life by social learning, which will result in a sense of collective self-esteem to solve a problem (Wang et al. 2020). There are a set of factors in this social learning and recognition, which strengthens resilience. These factors include the culture of collectivism and belief in religion and God. However, some attitudes and beliefs take precedence over others, and individualistic culture causes savagery in public behaviour (e.g. rushing to stores and decrease in tissues and masks), which reduces public resilience.

Psychological factors are also effective in developing the image of government institutions and the creation of attitudes towards them in public opinion. The image of government institutions itself is a sociological factor as resilience will increase if the public has a positive attitude towards the government and considers health institutions to be effective, which will result in a higher public trust. This increases the authority and cohesion of a government in decisions, and strengthens national cohesion (Hawryluck et al. 2004). Another point is the government's trust in the system's strength and abundance of infrastructure, which has activated these capacities before and during the crisis through innovation and with no bureaucracy so that it could increase jihadi activities to deal with the COVID-19 crisis. Good governance, transparency, efficiency, and macroeconomic and microeconomic stability, small businesses and low social transparency are other factors affecting national resilience. In addition, countries with weaknesses in these areas have experienced a reduced resilience during the COVID-19 crisis (Al-Mandhari et al. 2020). This issue should be strengthened by governments as governance, all of its dimensions, affect psychological factors, and their weakness can decrease the effectiveness of strengths in psychological factors and public activities, and thereby reduce public resilience. Moreover, resilience is an important factor in dealing with COVID-19 at the individual, religious and religiosity levels, which are covered in the current research.
The coronavirus disease 2019 was a great wake-up call for humanity, and fewer incidents have had such an impact. This wide range of general and global disasters has raised new questions for humanity and has caused unprecedented situations, all of which require wise and thoughtful deliberation and confrontation ( $\mathrm{Xu}$ et al. 2020). The coronavirus disease 2019 was a serious disaster, which, on the one hand, was a great threat to human society, and, on the other hand, provided unique opportunities that could be realised through proper planning. The damages caused by COVID-19 are observed in various aspects of the modern world. At first, this global phenomenon was thought to be transient, but today, everyone knows that this is a mediumterm phenomenon, which will cause a lot of damage. There has been a negative impact of COVID-19 on the livelihood of people and the economic systems of countries, which has been observed worldwide. All over the world, people are dealing with COVID-19-associated economic shocks, which have caused new challenges in economic systems, including jobs, services and distribution. Similarly, the social system and social bonds have faced serious threats caused by COVID-19. The instructions proposed to deal with global disasters have weakened social bonds. Whilst a part of this problem has been solved with novel technologies, some parts of the issue are irreparable. The fact that the bonds amongst family members have decreased is not a small matter. In addition to its impact on social systems, COVID-19 has posed challenges in scientific bonds, and religious and faith issues and bonds. These damages have emerged at economic, social, scientific and cultural dimensions. The most important effects of the phenomenon include its psychological, personality and internal impacts on humans, which, if left untreated, will have destructive consequences and will cause numerous problems for healthcare systems (Van Bortel et al. 2016).

In addition to the mentioned points, the healthcare system has dealt with various problems in this regard. Nevertheless, studies were mainly focused on the psychological, mental, personality and internal damages of this global disaster (McAlonan et al. 2007). The impact of this disease on the psych of patients can be the basis for further damages. In addition, the internal damage caused by the disease can engage other areas as well. However, other damages can be easily treated if humankind is able to manage its internal factors suitably and follow up treatment properly. Here, we come to the issue of tolerance, resistance and resilience. Having a cohesive and organised inner world is what can put human beings in a sublime position and protect them from stress and insecurity. A person who is organised from within, and has worldviews and control over oneself is able to manage his or her social and individual problems, deal with challenges and be relieved from depression (Singh \& Gujral 2018).

\section{Islam and COVID-19 resilience}

In this study, we come to the question of what is the model of psychological resilience of Islam against these challenges? Which is the model known as patience and resistance. The 
issue of resilience has been emphasised in the Quran (Surah Al-Baqarah, Ayat 45, 153, 184, 249, 286; Surah Al-'Asr, Ayat 3; Surah Al-A'raf, Ayat 128; Surah Ali 'Imran, Ayat 200; Surah At-Talaq, Ayat 7, etc.), as well as in the Islamic tradition, ethics and mysticism. In the Islamic religious culture, resilience is recognised as patience in adversity. Faithful living is a pattern arising from the text of religion (Hashmi et al. 2020). This internal resilience, which has external symbols, has various dimensions, as mentioned by moral scholars, and includes knowledge and insight, emotional and spiritual matter, manifestation in behaviours and expression in words. We have to adhere to several components if we aim to use the same model of resilience in disasters and incidents (Hashmi et al. 2020). The first component of Islamic resilience includes knowledge, insight and correct explanation of the incident. This component is the basis of human resilience and resistance to life events and challenges (Rokib 2012). It is extremely important to provide a correct explanation of a complex phenomenon. A very coherent view and systematic interpretation are presented in our philosophical thinking about disasters and events (Rokib 2012). This interpretation is rational and promising. Considering a natural phenomenon as an unfortunate event that is created without wisdom leads to passivity and depression. In Islamic interpretation, whilst natural disasters could be a reflection of human misconduct and a type of punishment, they can have many good things (Wildman et al. 2020). These events are sometimes an atonement for sins and sometimes a step towards human excellence.

Furthermore, all of these issues are a test, and the hand of God helps humanity and can provide goodness in all difficult phenomena, whether they are worldly blessings and could affect the scientific progress or they are manifestations that will emerge in the afterlife (Al Eid \& Arnout). In Islam, natural disasters are not pure evil as they are a tool for human excellence (Azarbaijani 2006). This hopeful perspective and positive attitude towards events are observed throughout Islamic interpretations. In the second component, Islam presents a system of moral virtues and spirits to human beings, which have important incentives in the Shari'a. Shari'a is synonymous with religion in the general sense and is sometimes used interchangeably. Shari'a means belief in the unseen principles from the perfection of purity of heart and purity of intention, and all the prophets of the people

TABLE 1: Cronbach's alpha coefficient of the questionnaire.

\begin{tabular}{lcc}
\hline Variables or components & Number of items & Cronbach's Alpha \\
\hline Religiosity & 20 & 0.86 \\
Psychological resilience & 25 & 0.89 \\
Total questionnaire & 45 & 0.93 \\
\hline
\end{tabular}

TABLE 2: Statistical indicators of sampling adequacy.

\begin{tabular}{llc}
\hline Test & Variable & Value \\
\hline $\begin{array}{l}\text { Kaiser-Meyer-Okin Measure of } \\
\text { Sampling Adequacy }\end{array}$ & KMO & 0.874 \\
Bartlett's Test of Sphericity & Approx. Chi-Square & 9531.167 \\
& $d f$ & 535 \\
& Sig. & 0.000 \\
\hline
\end{tabular}

invited to it and there is no difference between them in this regard, and therefore, in this sense, it is one with the concept of religion. The third component is the component of the behavioural systems, to which Islam has called us. In general, Islam emphasises social interactions. Islam has an ethical, social and jurisprudential system, which calls man towards social solidarity. It also emphasises avoidance of ingratitude and dishonour, and maintaining sanctity in the most difficult situations even in speech. This Islamic theory is based on the spirit of tolerance, relying on God, and not giving up in the face of events. The main components of Islamic resilience include the moral, behavioural, legal-jurisprudential system and eliminating individualism, having a social viewpoint, helping people, solidarity, social cooperation values and the system of words and literature of language and beautiful speech free of complaints. What is mentioned here is a psychological model that empowers human beings against events. Along with a resistant spirit, this accurate interpretation should result in social behaviours at the individual and social levels. The economic system, industry, market and authorities of our country must have this comprehensive realisation in different arenas that the moral and spiritual system affects our planning.

\section{Methods}

This study was performed on 550 Muslim citizens from three cities of Indonesia: Aceh, Semarang, and Jakarta, who recovered from COVID-19. The participants were selected by a simple available sampling method during four months and by face-to-face communication, and 536 questionnaires returned by the subjects were identified as appropriate and entered into the research. In this regard, data were collected using a 20-item questionnaire by Azarbaijani (2006) (to assess religiosity) and using a 25-item psychological resilience questionnaire by Mohammadi et al. (2006). The items were scored based on a five-point Likert scale from one (completely disagree) to five (completely agree) (Appendix 1). Content validity was applied to evaluate the validity of the tools. In this respect, the questionnaires were provided to five faculty members, who had conducted numerous similar studies in the past. After studying the questionnaires, they only made suggestions to improve the text of the questionnaire and increase its comprehensiveness, and approved its generality. Moreover, the reliability of the questionnaires was confirmed by distributing 30 tools amongst the statistical sample and determining it through a Cronbach's alpha test using SPSS version 16 software.

The values of Cronbach's alpha above 0.7 confirmed the reliability of the measuring instrument and the probability of using it as a basis for further work (Table 1). In this study, the Kaiser-Meyer-Olkin (KMO) test was used to measure the adequacy of sampling, the results of which were indicative of the appropriate volume of statistical sample used for the research study. In this study, the KMO statistic was 0.874 , which meant that the sample size was suitable for research (Table 2). However, the value of the Bartlett test showed that 
the Chi-square divided by its $d f$ was below two, which was an appropriate range for conducting the research.

Data analysis was performed in SPSS using the KolmogorovSmirnov test (to evaluate the normal distribution of the data) and Pearson's correlation coefficient (to assess the relationship between variables). In addition, the theoretical framework of the research was tested, and the impact factor was estimated.

Table 3 presents the results of the Kolmogorov-Smirnov test, according to which variables with a significance level $>0.05$ had a normal distribution. Therefore, we were allowed to use parametric tests in the statistical analysis process, which assessed the relationship between the variables.

\section{Findings}

Moreover, the $t$-test of a statistical community (mean) was applied in this study to assess the status of each of the research variables in the evaluated society. According to Landau (2019), the one-sample $t$-test is used to determine whether an unknown population mean is different from a specific (common or standard) value or even a case. In this test, a mean value above the contractual value of three (the moderate value) is favourable. It is notable that the test was implemented in SPSS. The test determines the status of each research variable, according to which recommendations can be made to improve the variables. Table 4 shows the results of the one-sample $t$-test.

All values had a significance level of $<0.05$ during the analysis of research variables. The values of these variables were above the moderate value of community because of the positive $\mathrm{T}$ statistic. Therefore, their status was reported to be appropriate. It could be expressed that the value of these variables was more than the mean value of society, and their status was estimated to be appropriate. In addition, the Pearson correlation coefficient was used to examine the relationship between research variables.

First hypothesis: there is a significant relationship between religiosity and psychological resilience of citizens.

$\mathbf{H}_{0}: r=0$

$\mathbf{H}_{0}: r \neq 0$

TABLE 3: Kolmogorov-Smirnov test results.

\begin{tabular}{lccc}
\hline Variable & Value K-S & Significance level & Result \\
\hline Religiosity & 0.954 & 0.624 & Normal \\
$\begin{array}{l}\text { Psychological } \\
\text { resilience }\end{array}$ & 0.866 & 0.667 & Normal \\
\hline
\end{tabular}

As shown in Table 5, the relationship between the variables was considered to be statistically significant, as the significance level $(\operatorname{sig}=0.000)$ was lower than the predicted error level $(\alpha=0.05)$. In addition, $\mathrm{H}_{0}$ and $\mathrm{H}_{1}$ were rejected and confirmed, respectively, considering that the correlation coefficient was reported to be 0.657 . Therefore, at a $95 \%$ confidence level, there was a significant and direct relationship between religiosity and psychological resilience. In other words, improvement in religiosity led to a higher psychological resilience against COVID-19 in citizens.

\section{Implications and recommendations}

Unfortunately, the current outbreak of COVID-19 has caused severe anxiety and stress in people. Meanwhile, fear of the disease has more affected people mentally, compared with the disease itself. This has become a problem in our lives. Meanwhile, determining coping mechanisms against life challenges by researchers can affect people's psychological aspects and improve their psychological resilience. This will help humans to better deal with their problems and cope with any type of crisis in near future. Psychological resilience increases the capacity of people to deal with stress and critical situations, making them able to adapt to and defeat difficulties. Therefore, people can reconstruct their lives after passing a crisis and stressful time, which can also be explained by religious sciences. Being resilient does not mean to eliminate stress and difficult situations from life; rather, it means being able to cope with the situation and be flexible to life pressures.

The results of this study revealed that religiosity affected psychological resilience by $p=0.784$. It means that the improvement of religiosity will improve psychological resilience against COVID-19 in people. In addition, the Muslim citizens in three cities of Indonesia, Aceh, Semarang and Jakarta, had an acceptable level of religious beliefs (mean $=4.02$ ), which could be the reason behind their high psychological resilience against COVID-19 (mean $=3.99)$.

\section{Conclusion}

Psychological resilience does not limit stress and will not remove life problems altogether; rather, it enables individuals

TABLE 5: Pearson's test results for the assessment of the first hypothesis.

\begin{tabular}{lcccc}
\hline Variable & $\begin{array}{c}\text { Number of } \\
\text { samples }\end{array}$ & $\begin{array}{c}\text { Correlation } \\
\text { coefficient }\end{array}$ & Error rate & $\begin{array}{c}\text { Level of } \\
\text { significance }\end{array}$ \\
\hline $\begin{array}{l}\text { Religious beliefs } \\
\rightarrow \text { Psychological }\end{array}$ & 536 & 0.784 & 0.05 & 0.000 \\
resilience & & & & \\
\hline
\end{tabular}

TABLE 4: One-sample $t$-test results.

\begin{tabular}{lccccccc}
\hline Variable & Mean & Standard deviation & T Statistic & Degree of freedom & Significance level & Mean difference & Status \\
\hline $\begin{array}{l}\text { Religiosity } \\
\begin{array}{l}\text { Psychological } \\
\text { resilience }\end{array}\end{array}$ & 4.02 & 0.382 & 12.32 & 535 & 0.000 & 0.98 & Appropriate \\
\hline
\end{tabular}


to properly deal with their problems ahead, overcome difficulties and move forward on the path of life. Psychological resilience can be taught, and other people can learn and improve it. In fact, resilience is the ability to adapt to stressful and challenging situations. Religiosity and religious beliefs have a significant impact on calming people down during stress and shock. For instance, praying plays a crucial role in emotional relief and the reduction of psychological stress. In addition, praying has been pointed out as an important factor in Islamic teachings and verses. Those who say prayers will experience tranquility and tolerance against problems, and afflictions. Belief in destiny, on the one hand, and being successful in the divine experiment, on the other hand, can improve people's ability to deal with their problems and experience less stress in life. The fact that these sufferings and problems are an inseparable part of all people should be explained through religious teachings. In this regard, the nature and type of problems do not matter, and the most important thing is how to react to them. Should we lose control or should we deal with it? A person who trusts in God does not fear the unknown. According to the Quran, 'and endure patiently whatever befalls you' (Surah Luqman/Verse 17), because surrender is one of the tools used by Satan to destroy man. These results highlighted the importance of religiosity and reliance on religious teachings in having higher resilience during the COVID-19 pandemic.

\section{Acknowledgements}

The authors would like to thank the citizens for their participation and engagement in the study.

\section{Competing interests}

The authors declare that they have no financial or personal relationships that may have inappropriately influenced them in writing this article.

\section{Authors' contributions}

L.K.I., T.N.I. and L.N.K. contributed equally to this research article.

\section{Ethical considerations}

This research followed all ethical standards for research without direct contact with human or animal subjects.

\section{Funding information}

This research received no specific grant from any funding agency in the public, commercial or not-for-profit sectors.

\section{Data availability}

Data are available from the corresponding author, L.K.I., upon reasonable request.

\section{Disclaimer}

The views and opinions expressed in this article are those of the authors and do not necessarily reflect the official policy or position of any affiliated agency of the authors.

\section{References}

Al Eid, N.A. \& Arnout, B.A., 2020, 'Crisis and disaster management in the light of the Islamic approach: COVID-19 pandemic crisis as a model (a qualitative study using the grounded theory)', Journal of Public Affairs 20(4), e2217. https://doi. org/10.1002/pa.2217

Al-Mandhari, A., Samhouri, D., Abubakar, A. \& Brennan, R., 2020, 'Coronavirus Disease 2019: Preparedness and readiness of countries in the Eastern Mediterranean Region', Eastern Mediterranean Health Journal 26(2), 136-137. https://doi org/10.26719/2020.26.2.136

Azarbaijani, M., 2006, Preparation and testing of religious orientation based on Islam, Seminary and University Research Institute, Qom.

Eskandari, H., Lotfi, A., Motamedi, A., Delavar, A., Dehghani Poudeh, H., 2016, 'Analytical study of national psychological resilience', Science and Research Journal of Ministry of Science 28(4), 45-60.

Hashmi, F.K., Iqbal, Q., Haque, N. \& Saleem, F., 2020, 'Religious cliché and stigma: A brief response to overlooked barriers in COVID-19 management', Journal of Religion and Health 59(6), 2697-2700. https://doi.org/10.1007/s10943-02001063-y

Hawryluck, L., Gold, W.L., Robinson, S., Pogorski, S., Galea, S. \& Styra, R., 2004, 'SARS control and psychological effects of quarantine, Toronto, Canada', Emerging Infectious Diseases 10(7), 1206. https://doi.org/10.3201/eid1007. 030703

Keshtkar, H.M. \& Dehghan, S., 2018, 'Conceptual model of social innovation to achieve power strength', Journal of Parliament and Strategy 25(94), 39-68.

Landau, S., 2019, A handbook of statistical analyses using SPSS, Chapman \& Hall, Boca Raton, London, New York \& Washington, D.C.

McAlonan, G.M., Lee, A.M., Cheung, V., Cheung, C., Tsang, K.W., Sham, P.C. et al., 2007, 'Immediate and sustained psychological impact of an emerging infectious disease outbreak on health care workers', The Canadian Journal of Psychiatry 52(4), 241-247. https://doi.org/10.1177/070674370705200406

Mohammadi, M., Jazayeri, A., Rafie, A., Joukar, B. \& Pourshahbaz, A., 2006, 'Resilience factors in individuals at risk for substance abuse', Journal of Psychology 1(2), 193-214.

Molavi, Z., Tahmasebi, R., DanaeeFard, H. \& Hamidizadeh, A., 2019, 'Bureaucphobia and perceived national resilience', Quarterly Journal of Public Organzations Management 7(2), 83-96.

Nishiura, H., Jung, S.M., Linton, N.M., Kinoshita, R., Yang, Y., Hayashi, K. et al., 2020, 'The extent of transmission of novel coronavirus in Wuhan, China, 2020', Journal of Clinical Medicine 9(2), 330-335.

Redadi, A., Najafi Farashah, A.M. \& Azarfar, A., 2016, 'Modeling structural relationships and prerequisites for constructive concepts of resistance economics using Interpretive-structural Approach (ISM)', Basij Strategic Sciences 19(71), 31-55.

Rokib, M., 2012, 'The significant role of religious group's response to natural disaster in Indonesia: The case of Santri Tanggap Bencana (Santana)', Indonesian Journal of Islam and Muslim Societies 2(1), 53-77. https://doi.org/10.18326/ ijims.v2i1.53-77

Singh, G. \& Gujral, H.K., 2018, 'Moderating effect of resilience on role stress: A critical review', ZENITH International Journal of Multidisciplinary Research 8(1), 114-122.

Van Bortel, T., Basnayake, A., Wurie, F., Jambai, M., Koroma, A.S., Muana, A.T. et al., 2016, 'Psychosocial effects of an Ebola outbreak at individual, community and international levels', Bulletin of the World Health Organization 94(3), 210. https:// doi.org/10.2471/BLT.15.158543

Wang, C., Pan, R., Wan, X., Tan, Y., Xu, L., Ho, C.S. et al., 2020, 'Immediate psychological responses and associated factors during the initial stage of the 2019 coronavirus disease (COVID-19) epidemic among the general population in China', International Journal of Environmental Research and Public Health 17(5), 1729. https://doi.org/10.3390/ijerph17051729

Weichselgartner, J. \& Kelman, I., 2015, 'Geographies of resilience: Challenges and opportunities of a descriptive concept', Progress in Human Geography 39(3), 249-267. https://doi.org/10.1177/0309132513518834

Wildman, W.J., Bulbulia, J., Sosis, R. \& Schjoedt, U., 2020, 'Religion and the COVID-19 pandemic', Religion, Brain and Behavior 10(2), 115-117. https://doi.org/10.1080/ 2153599X.2020.1749339

Xu, K., Cai, H., Shen, Y., Ni, Q., Chen, Y., Hu, S. et al., 2020, 'Management of corona virus disease-19 (COVID-19): The Zhejiang experience', Journal of Zhejiang University (Medical Science) 49(1), 147-157. 


\section{Appendix 1}

\section{0-item religiosity questionnaire by Azerbaijani (2006)}

The items were scored based on a five-point Likert scale from one (completely disagree) to five (completely agree):

1. I know the way to happiness in following the teachings of Islam.

2. I feel close to God.

3. I do not consider myself disappointed with God.

4. Quranic teachings are the best guide of human life.

5. The religion of Islam has provided the most complete programs for human happiness.

6. I always want to know more about God and the religion of Islam.

7. I am bound to Islam in all areas of life.

8. I read the Quran regularly.

9. I believe in life after death, heaven and hell.

10. I get the necessities of my life through lawful means.

11. In my free time I read books and religious prayers.

12. I always put honesty at the top of my agenda.

13. Sometimes I give part of my property to the poor.

14. I practice cleanliness according to Islamic teachings.

15. I do not approach activities that are forbidden in Islam.

16. I try to be in the group of true believers in Islam.

17. I start my day in remembrance of God and thank God for the end of the day.

18. I usually attend mosques and daily prayers.

19. I fast during the month of Ramadan.

20. I believe that Prophet Mohammad is the last prophet of God and Islam is the most perfect religion of God.

\section{5-item psychological resilience questionnaire by Mohammadi et al. (2006)}

1. I am able to adapt when changes occur; because I believe in God supports.

2. I have one close and secure relationship.

3. In my life, God helps me.

4. I can deal with whatever comes my way.

5. Faith in God gives me confidence.

6. I try to see the humorous side of things when I am faced with problems.

7. Having to cope with stress can make me stronger.

8. I tend to bounce back after illness, injury or other hardships.

9. I believe most things happen for a reason.

10. I make my best effort, no matter what.

11. I believe I can achieve my goals with God's help, even if there are obstacles.

12. Even when hopeless, I do not give up.

13. In times of stress, I know where to find help.

14. Under pressure, I stay focused and think clearly.

15. I prefer to take the lead in problem-solving.

16. I am not easily discouraged by failure.

17. I think of myself as a strong person when dealing with life's challenges and difficulties.

18. I can make difficult decisions.

19. I am able to handle unpleasant or painful feelings like sadness, fear, and anger.

20. I have to act on a hunch.

21. I have a strong sense of purpose in life.

22. I feel like I am in control.

23. I like challenges.

24. I work to attain goals.

25. I take pride in my achievements. 